\title{
CONGENITAL METHEMOGLOBINEMIA. A CLINICAL AND BIOCHEMICAL STUDY OF A CASE ${ }^{1}$
}

\author{
By HOWARD A. EDER,² CLEMENT FINCH, AND RALPH W. MCKEE \\ (From the Departments of Medicine and Biological Chemistry, Harvard Medical School, and \\ the Medical Clinic, Peter Bent Brigham Hospital, Boston)
}

(Received for publication February 20, 1948)

Congenital methemoglobinemia is an unusual condition in which a large amount of intracellular hemoglobin exists as methemoglobin-pigment in which the hemoglobin iron is in the ferric state and incapable of carrying oxygen. The congenital type of methemoglobinemia is present from birth and is characterized by the constancy of the level of methemoglobin, by the relatively mild associated symptoms, and by polycythemia with no evidence of excessive blood destruction. There are 15 verified cases of congenital methemoglobinemia in the literature (1-10) and 10 additional cases of idiopathic methemoglobinemia (11-15) in which definite information as to the congenital aspect was lacking. In all of these cases the abnormal pigment was identified spectroscopically.

The subject of this study was a young man who presented the typical clinical picture of congenital methemoglobinemia. We have now followed him for five years-sufficient time to evaluate different forms of therapy for this condition.

\section{CASE HISTORY}

F. S., a 23-year-old public accountant, was admitted in December 1942 because of persistent cyanosis. He was born a "blue baby" and had been continually cyanotic with no noticeable fluctuation of degree of cyanosis during all his life. He could not indulge in strenuous exercise because of dyspnea, easy fatigability and pounding temporal headaches. He took no drugs and had no gastro-intestinal symptoms and there was no family history of similar cyanosis.

Physical examination disclosed a well-developed young man, 5 feet 11 inches tall and weighing 207 pounds. His skin had a slate blue color which was especially apparent in his lips, ears and finger nail beds. His conjunctivae were congested and the veins in the optic fundi were dark and dilated. There were no abnormalities on examination of his heart and lungs. Blood pressure was

\footnotetext{
1 Read at the Meeting of the American Society for Clinical Investigation, Atlantic City, N. J., May 5, 1947.

2 Fellow of the Nutrition Foundation. Present address: The Rockefeller Institute for Medical Research, New York, N. Y.
}

130/90. He had no clubbing of his fingers, and his spleen and liver were not palpable.

Laboratory data: Hinton test for syphilis was negative; $\mathrm{RBC}$ was 6.5 million per $\mathrm{mm}^{3}$; hematocrit was 58 per cent; $\mathrm{Hb}$ was 19 gms. per $100 \mathrm{cc}$; WBC was 7,850 per $\mathrm{mm}^{3}$ with a normal differential count; reticulocytes were 2.2 per cent. Hypotonic saline fragility was normal. Bone marrow puncture showed only a normoblastic hyperplasia, consistent with his polycythemia. Urine and stool examinations were negative. Plasma proteins were $7.8 \mathrm{gms}$. per $100 \mathrm{cc}$. with $4.4 \mathrm{gms}$. of albumin; serum bilirubin was $0.5 \mathrm{mgm}$. per $100 \mathrm{cc}$. Venous pressure was 100 $\mathrm{cm}$. of water; circulation time was $14 \mathrm{sec}$. (decholin) ; vital capacity was 4 liters. Bromsulfalein excretion test showed a retention of 5 per cent of the dye in the serum in 30 min. EKG was normal; BMR was -15 and -12 per cent. X-ray of the chest showed normal lung fields with a heart of normal size and shape. X-ray of the large bowel showed no abnormalities. Spectroscopic examination of the blood showed the absorption bands characteristic of methemoglobin. By difference between total pigment and oxygen capacity it was estimated that 45 per cent of the total blood pigment was in the form of methemoglobin. Subsequent determinations of methemoglobin were done by the colorimetric method of Evelyn and Malloy (16). This method was checked by the carbon monoxide capacity method of Van Slyke and Hiller (17) and found to be accurate to $\pm 0.2 \mathrm{gm}$. in our hands.

After a control period of one week in which the level of methemoglobin remained constant he was given 90 mgm. of methylene blue intravenously. In 10 minutes half of the methemoglobin disappeared and by 30 minutes over 95 per cent had disappeared. He was then able to exercise vigorously without headaches and breathlessness which had previously so limited his activity. During the course of the following five years he was treated with ascorbic acid and with methylene blue by mouth. It was found that $240 \mathrm{mgm}$. of methylene blue in enteric coated tablets per day were well tolerated and were sufficient to keep him free of cyanosis. Coincident with this treatment polycythemia and reticulocytosis subsided. No toxic effects from this long-sustained treatment have been observed.

The identity of the abnormal pigment in this case was established spectroscopically as methemoglobin. There was a well-defined absorption band at $630 \mu$ which disappeared after addition 


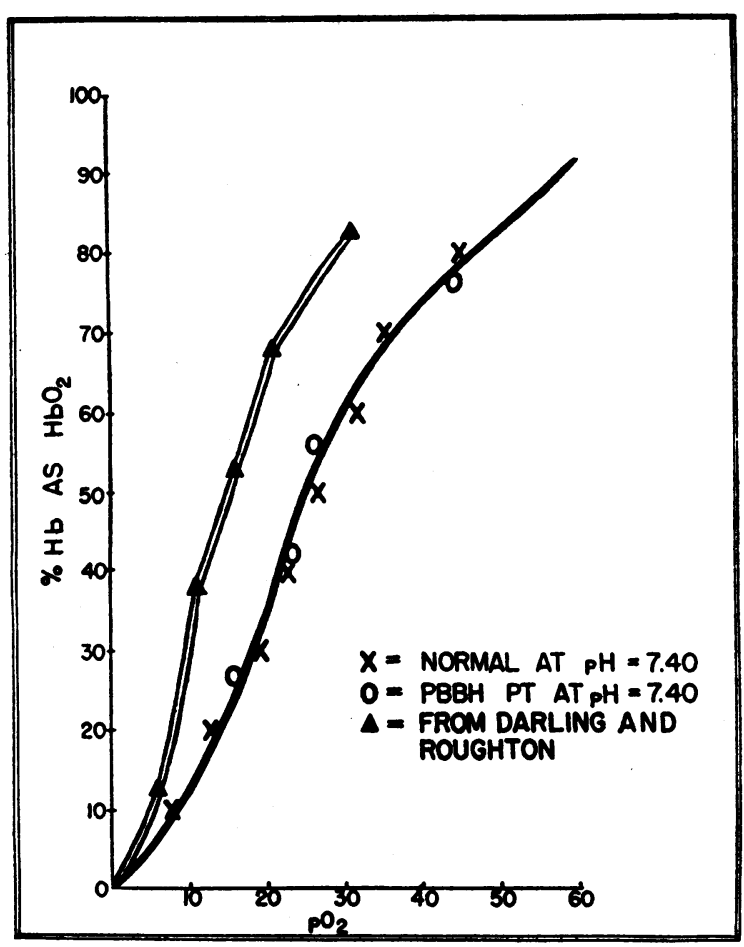

Fig. 1. Oxygen Dissociation Curve of Patient with 30 Per Cent Methemoglobin Superimposed on Normal Oxygen Dissociation Curve

This is compared with the curve of Darling and Roughton on blood also containing about 30 per cent methemoglobin. of sodium cyanide or of sodium hydrosulfite $\left(\mathrm{Na}_{2} \mathrm{~S}_{2} \mathrm{O}_{4}\right)$ in vitro, or after injection of methylene blue in vivo.

Symptoms present in our patient and in others reported were those of anoxia due to the decreased oxygen-carrying capacity of the blood. In addition to this, Darling and Roughton (18) have recently described an additional adverse effect of the presence of methemoglobin on oxygen transport; this is a shift to the left of the oxygen dissociation curve as also occurs in carbon monoxide poisoning. This change hinders the transfer of oxygen from the blood to tissue.

The oxygen dissociation curve on the blood of our patient when his methemoglobin level was 30 per cent was determined by us and by the Harvard Fatigue Laboratory (Figure 1). In both cases the points fell on the normal curve and showed none of the changes described by Darling and Roughton. In four other cases in which oxygen dissociation curves were made, one (12) showed no shift while three showed definite shifts of the curve $(1,14,19)$.

\section{STUDIES OF THE MECHANISM}

\section{Site of the defect}

To ascertain whether the factor responsible for the high methemoglobin' content of the erythro-

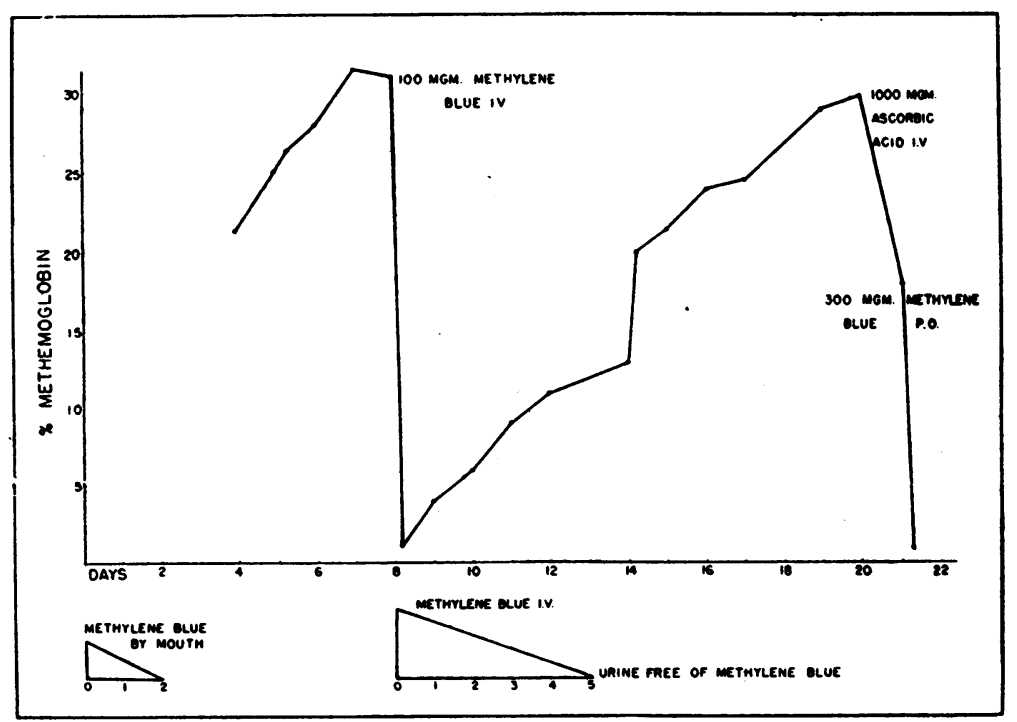

Fig. 2. Rate of Methemoglobin formation in Patient F. S. after Cessation of Methylene Blue Therapy 


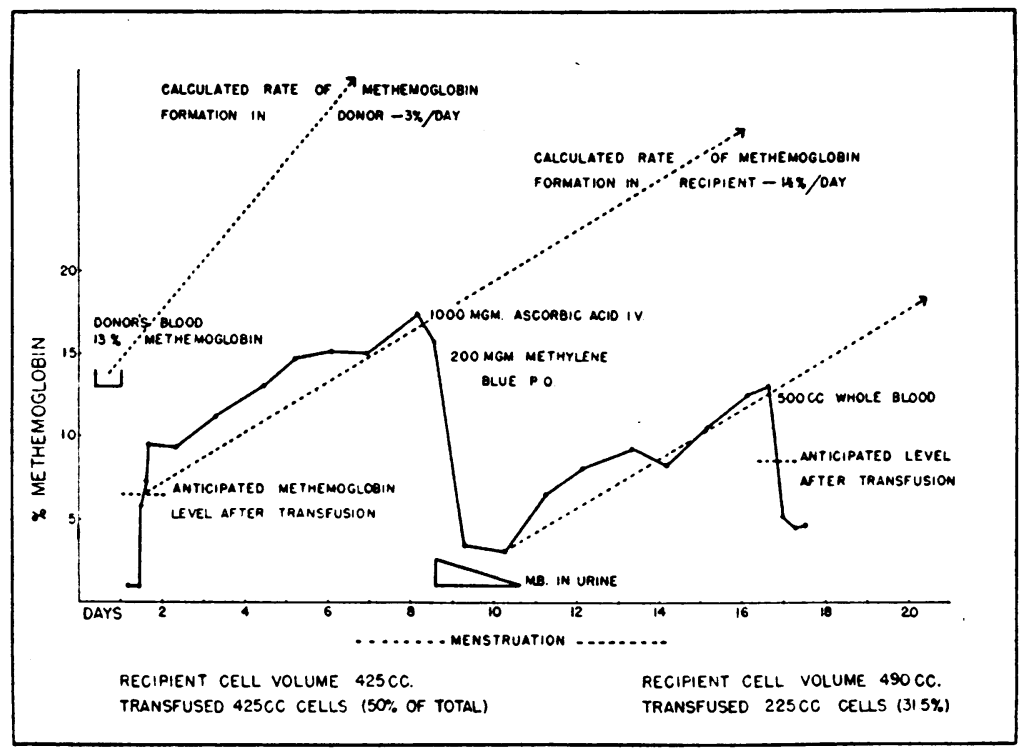

Fig. 3. Behavior of Blood from Patient F. S. after Transfusion into a Patient with Refractory Anemia

cytes was in the cells or the plasma the patient's red cells were incubated with compatible normal serum, and normal cells were incubated with the patient's serum. At the end of 24 hours in the former the methemoglobin was not significantly reduced, and in the latter methemoglobin was not produced. This confirmed previous in vitro observations that there was no plasma factor of importance $(2,10)$.

To ascertain whether there was any factor in the body, outside the red cells, that influenced methemoglobin formation in the cells, the following in vivo experiment was performed. The methemoglobin in the patient's circulation was changed to normal hemoglobin by methylene blue administration, and the subsequent rate of methemoglobin formation in the patient was observed for 13 days (Figure 2). There was an average daily transformation of 3 per cent of the total hemoglobin into methemoglobin. At a time when methylene blue therapy had changed the patient's methemoglobin nearly all to normal hemoglobin he was bled and $225 \mathrm{cc}$. of his erythrocytes were infused into a patient with refractory anemia (Figure 3 ). This subject was chosen as a recipient because there would be no new hemoglobin formation to complicate the experiment. The volume of cells infused was calculated to be exactly equal to the volume of the recipient's own circulating erythrocytes, as estimated from determination of her plasma volume (T-1824 method) and her hematocrit. After the infusion the rate of methemoglobin formation per day was 1.5 per cent of the total hemoglobin. It therefore appeared that the infused cells were forming methemoglobin in the recipient at the same rate at which they formed it in the donor. This result makes it appear improbable that there were any abnormal factors outside the red cells of the methemoglobinemic patient that influenced the formation of methemoglobin.

\section{Failure of methemoglobin reduction}

A solution of hemoglobin obtained by laking human red cells when exposed to an atmosphere of 95 per cent air and 5 per cent carbon dioxide will be completely converted to methemoglobin in about five days (Figure 4). This was equally true of hemoglobin from normal human subjects and of hemoglobin from our patient. Intact red cells possess a mechanism which prevents this from occurring and maintains the hemoglobin iron in the ferrous state. When we incubated normal cells in the rocker perfusion apparatus (20) no methemoglobin was formed as long as glucose was present in the media (Figure 4 ). When sodium nitrite was added to normal cells under these conditions methemoglobin was formed and then 


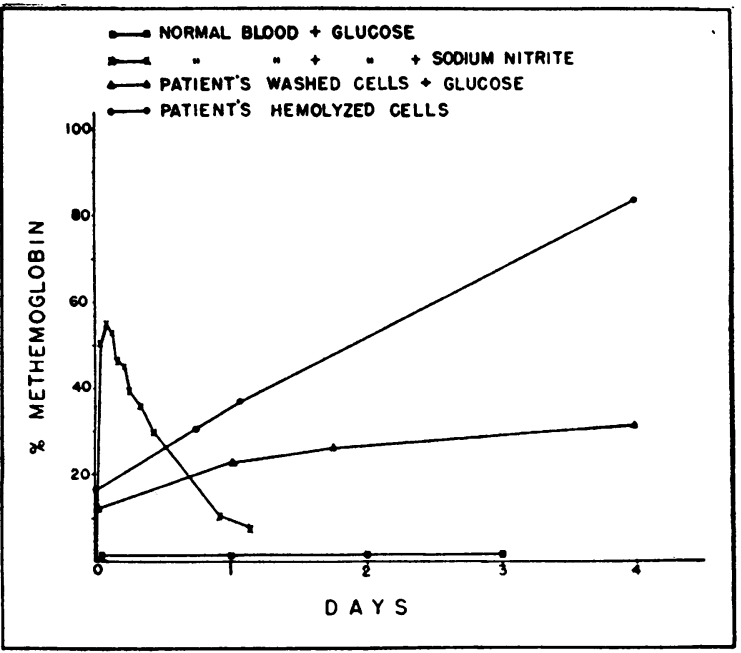

Fig. 4. Methemoglobin Levels after in Vitro INcubation of Hemolyzed Cells and Intact Cells in the Rocker Perfusion Apparatus

The in vitro effect of sodium nitrite on normal cells is also shown.

completely reduced within 12 hours. When cells from our patient containing methemoglobin were incubated in the apparatus there was no reduction and the methemoglobin level rose to about 30 per cent. This inability of the patient's cells to reduce methemoglobin corroborates previous in vitro observations $(2,6,10)$.
Studies of the in vivo reduction rates of methemoglobin were performed by injecting, intravenously, $0.5 \mathrm{gm}$. of sodium nitrite into normal individuals and into the patient. Nitrite was chosen because it rapidly produced methemoglobin and was itself entirely gone from the blood stream by $60-90$ minutes (21). In both the normal subject and the patient the sodium nitrite caused formation of about 2.5 gms. of methemoglobin per $100 \mathrm{cc}$. of blood within 40 minutes. On the other hand, after three hours, half of the methemoglobin formed had disappeared in the normal subject while in the patient the methemoglobin level showed no tendency to fall even after seven hours (Figure 5). This indicates that the normal mechanism for methemoglobin reduction fails to operate in this patient.

\section{The methemoglobin reduction mechanism of the erythrocyte}

In vitro studies of methemoglobin reduction in the red cell have shown that this is an enzymatic process in which glucose and lactate act as hydrogen donors (22-24). In view of this relationship, the carbohydrate metabolism of our patient's erythrocytes was investigated. The resting oxygen consumption measured in the Warburg manometric apparatus of $2 \mathrm{ml}$. of the patient's cells

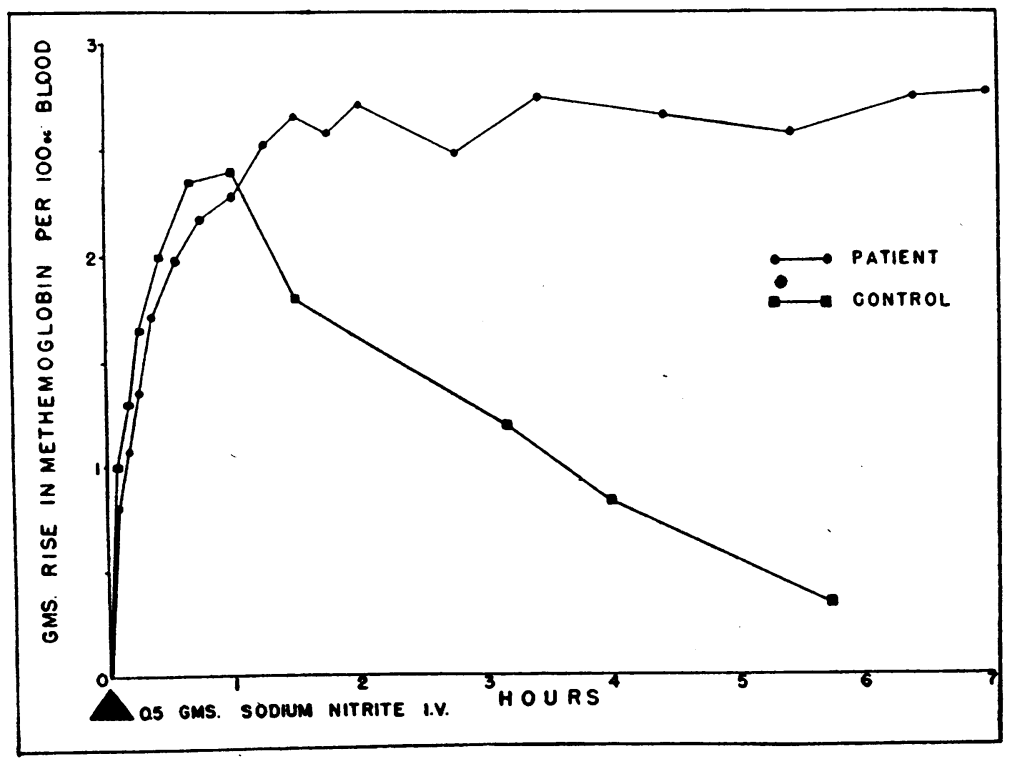

Fig. 5. Effect of 0.5 Gm. Sodium Nitrite on Patient F. S. and on a Normal Subject 
TABLE I

Chemical survey of factors involved in carbohydrate metabolism in patient's blood

\begin{tabular}{|c|c|c|c|c|c|c|c|c|}
\hline & \multirow[b]{2}{*}{$\begin{array}{c}\text { Glucose } \\
\text { utilization }\end{array}$} & \multirow[b]{2}{*}{$\begin{array}{c}\text { Lactate } \\
\text { utilization }\end{array}$} & \multirow[b]{2}{*}{$\begin{array}{l}\text { Whole blood } \\
\text { inorganic P }\end{array}$} & \multicolumn{5}{|c|}{ RBC } \\
\hline & & & & 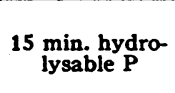 & $\begin{array}{l}\text { Acid } \\
\text { soluble P }\end{array}$ & Total P & $\begin{array}{c}\text { Resting } \mathrm{O}_{2} \\
\text { consumption }\end{array}$ & $\begin{array}{c}\text { Flavine } \\
\text { adenine } \\
\text { dinucleotide }\end{array}$ \\
\hline Normal average & $\begin{array}{l}\text { mgm. per } \\
\text { cent per hour } \\
10-20(28)\end{array}$ & $\begin{array}{c}\text { mgm. per } \\
\text { cent per hour } \\
0-5\end{array}$ & $\begin{array}{l}\text { mgm. per cent } \\
2.4-3.5(29)\end{array}$ & $\begin{array}{c}\text { mgm. per cent } \\
8.1-10.5(30)\end{array}$ & $\begin{array}{c}\text { mgm. per } \\
\text { cent } \\
50-60(27)\end{array}$ & $\begin{array}{l}\text { mgm. per cent } \\
47-114(29)\end{array}$ & $\begin{array}{c}\text { mm. } \\
\text { hour per } \\
\text { of cells } 2 \text { cc. } \\
10-30\end{array}$ & $\begin{array}{c}\text { gamma } \\
\text { per cent } \\
35\end{array}$ \\
\hline Patient & $\begin{array}{l}21.5 \\
22.2\end{array}$ & $0-4$ & $\begin{array}{l}2.5 \\
3.2\end{array}$ & $\begin{array}{l}12.2 \\
13.2\end{array}$ & $\begin{array}{l}56.4 \\
58.6\end{array}$ & $\begin{array}{l}112.7 \\
121.6\end{array}$ & 20 & 35 \\
\hline
\end{tabular}

was $22 \mathrm{~mm}^{3}$ in 30 minutes as compared with 19 mm..$^{3}$ in the normal control. Glycolysis as measured by glucose utilization (25) and lactate formation was normal. There was no lactate utilization. Flavine adenine dinucleotide in red cells was measured by the method of Ball et al. (26) using the enzyme system of d-amino acid oxidase with $d, 1$-alanine as substrate. ${ }^{3}$ The amount of enzyme present was the same as in a normal control. Values for the 15 minute hydrolysable $P$ of which the chief component is adenosine triphosphate were well within the normal range. Acid soluble $\mathrm{P}$ values comprising largely glycerol phosphate (27) were normal. Measurement of the other $\mathrm{P}$ partitions also showed nothing which indicated any abnormality of phosphorylation. These findings are summarized in Table I. To the extent of these studies we were unable to find any defect in the carbohydrate metabolism of the erythrocyte.

\section{Action of methylene blue}

Harrop and Barron in 1928 (31) demonstrated that the addition of methylene blue caused a tenfold increase in the oxygen consumption of mammalian red blood cells. Such an increase occurred to the same degree in our patient's erythrocytes as in the normal erythrocytes. This increase does not occur when the cells are washed free of glucose. When blood from the patient with congenital methemoglobinemia was treated with methylene blue in the presence of $100 \mathrm{mgm}$. per cent glucose there was complete reversion of the methemoglobin present to active hemoglobin. This

3 The standard flavine adenine dinucleotide and the d-amino acid oxidase was generously furnished by Dr. E. G. Ball. reversion was inhibited by $M / 300$ iodoacetate.

The beneficial therapeutic effect of methylene blue has been observed clinically for 15 years in secondary types of methemoglobinemia (32-34) and has been recently reported in congenital methemoglobinemia $(8,14)$. The marked therapeutic effect of methylene blue in our patient suggests that it replaces some constituent of normal cells that is necessary for the enzymatic reduction of methemoglobin and that this is lacking in the cells of our patient.

\section{Other oxidizing and reducing substances}

Since hydrogen peroxide is formed in certain enzymatic reactions and then is decomposed by intracellular catalase, it seemed possible that a deficiency of catalase could be responsible for the presence of methemoglobin. Accordingly the catalase content of the patient's erythrocytes was determined by a modification of the methods of Morgulis and Jusatz $(35,36)$ using $0.1 \mathrm{M}$ hydrogen peroxide in $0.02 \mathrm{M}$ phosphate buffer $(\mathrm{pH}$ 7.0) in a Warburg vessel. A normal catalase content of the red cells was found.

There are also substances present in blood cells and plasma that are capable of reducing methemoglobin. Ascorbic acid and glutathione are two such substances. This patient had blood levels of ascorbic acid averaging about $0.25 \mathrm{mgm}$. per cent compared to normal values of 1.5 to $2.0 \mathrm{mgm}$. per cent (37) despite adequate dietary ascorbic acid. The reduced glutathione level of the patient's whole blood was 20 mgm. per cent as compared to normal values of $40 \mathrm{mgm}$. per cent (38). One might consider that these substances represent a secondary line of defense of the body should the cell reconversion mechanism not func- 
tion. Certain circumstantial evidence indicates that this might be true. When hemoglobin or methemoglobin is injected intravenously in a dog an equilibrium point is reached at a methemoglobin concentration of 30 to 40 per cent of the total pigment $(39,40)$. By coincidence the 11 cases of congenital methemoglobinemia in which the per cent methemoglobin was reported showed the same equilibrium concentration.

When 2 gms. of ascorbic acid were given intravenously the methemoglobin level dropped from 25 to 15 per cent in ten hours. On doses of 300 to $500 \mathrm{mgm}$. of ascorbic acid per day for two weeks it was possible to lower the level of methemoglobin to 8-10 per cent of the total pigment. The sluggishness of this reaction and the fact that $\mathrm{d}$-ascorbic acid which is physiologically inert is equally as effective as the naturally occurring isomer suggest that the effect of ascorbic acid is due to its direct reducing action on methemoglobin $(41,42)$ rather than to restoration of the normal enzymatic reduction mechanism.

\section{DISCUSSION}

Studies on this case have emphasized the normal mechanism by which the organism is able to maintain the hemoglobin-methemoglobin equilibrium within the red cell at about 99.6 per cent in favor of the ferrous form which is essential for transport of oxygen (43). There is undoubtedly steady formation of methemoglobin in the red cell, but the cells are capable of reducing the methemoglobin as soon as it is formed. In congenital methemoglobinemia we have shown that this mechanism fails to function, and it is pertinent to look further into the nature of this mechanism.

In 1930 Warburg (22) showed that methemoglobin formed in intact red cells could be reduced by the cells when glucose was added. This reduction of methemoglobin was accompanied by the disappearance of the glucose and the appearance of pyruvic acid. This effect could be inhibited by iodoacetate. Gibson (44) has recently shown that methemoglobin reduction can occur in the presence of fluoride, but there is accumulation of phosphoglycerate. These findings indicate that the reduction of methemoglobin is coupled with glycolysis. In the glycolytic process diphosphopyridine nucleotide (coenzyme I) is reduced and is available for reduction of methemoglobin. (Red cells also contain triphosphopyridine nucleotide [coenzyme II] which becomes reduced by the direct oxidation of glucose through phosphogluconic acid.) Gutmann (45) has shown that reduced pyridine nucleotide will slowly reduce methemoglobin directly and this reaction can be accelerated by the addition of methylene blue. In normal cells it is likely that a flavoprotein which is present acts, as in other tissues, as a carrier between the pyridine nucleotide and the iron porphyrin. Little is known about the nature and properties of the flavoprotein in the red cell. Studies of Gibson have shown that in abnormal cells of his patients with congenital methemoglobinemia there is no defect in that part of the cycle concerned with formation of reduced pyridine nucleotide. Since glycolysis was shown to take place normally in the cells of our patient it is probable that reduced pyridine nucleotide is also formed normally in his cells. Since methylene blue has such a pronounced effect on reducing the methemoglobin in his cells it seems likely that the defect lies in these substances which catalyze the reduction of methemoglobin by reduced pyridine nucleotide. Gibson concluded that this defect in his patients was a deficiency of the flavoprotein, the coenzyme factor. In heart muscle this factor has been shown to be a flavine adenine dinucleotide (46). We analyzed for this substance using the d-amino acid oxidase as a test system and found it to be present in normal amounts in the cells of our patient. It is still a possibility that in his red cells this factor which is deficient is the flavine mononucleotide in which case the deficiency would not have been apparent by our method of analysis. It is also possible as both Kiese (47) and Gibson point out that the methylene blue does not function in a system already functioning actively (the coezyme I system) but rather enters into a secondary sluggish system (the coenzyme II system) and converts it into a rapidly active system. Further studies are necessary to find out what flavoproteins are present in the red cell and whether they have the capacity to reduce methemoglobin directly or require other as yet unknown factors. - 


\section{SUMMARY}

A case of congenital methemoglobinemia was studied which demonstrated the following characteristics :

1. The level of methemoglobin was approximately 40 per cent of the total pigment and remained constant from day to day.

2. In the untreated patient there was a compensatory polycythemia and no evidence of excessive blood destruction. Alteration of the $\mathrm{O}_{2}$ dissociation curve was not present.

3. Methylene blue and ascorbic acid were effective therapeutic agents.

4. The cause of the methemoglobinemia was shown to be the absence of a factor in the erythrocyte mechanism that in normal red cells rapidly reduces methemoglobin.

\section{ACKNOWLEDGMENT}

We should like to express our gratitude to Mr. Francis Stanley, the patient, without whose interest and cooperation these studies would have been impossible, and to Miss Katherine Hubbel for technical assistance.

\section{BIBLIOGRAPHY}

1. Hitzenberger, K., Autotoxische Zyanose (Intraglobuläre Methämoglobinämie). Wien. Arch. inn. Med., 1932, 23, 85.

2. Dieckmann, W. J., Methemoglobinemia. Arch. Int. Med., 1932, 50, 574.

3. Van Lier, H. W., Over de Parhaemoglobinaemieen. These, Utrecht, 1933.

4. Van Thienen, G. J., Methaemoglobinaemia. Nederl. tijdschr. v. geneesk., 1933, 77, 1086.

5. Van Heukelom, S., Intraglobulaire congenitale familiaire methemoglobinaemia. Geneesk. tijdschr. Nederl.-Indie, 1937, 77, 3054.

6. Lian, C., Frumusan, P., and Sassier, M., Méthémoglobinémie congénitale et familiale. Action favorable de l'acide ascorbique. Bull. et mém. Soc. méd. d. hôp. de Paris, 1939, 55, 1194.

7. Deeny, J., Murdock, E. T., and Rogan, J. J., Familial idiopathic methaemoglobinaemia with a note on the treatment of two .cases with ascorbic acid. Brit. M. J., 1943, 1, 721.

8. King, E. J., White, J. C., and Gilchrist, M., A case of idiopathic methaemoglobinaemia treated by ascorbic acid and methylene blue. J. Path. \& Bact., 1947, 59, 181.

9. Graybiel, A., Lilienthal, J. L., and Riley, R. L., The report of a case of idiopathic congenital (and probably familial) methemoglobinemia. Bull. Johns Hopkins Hosp., 1945, 76, 155.

10. Sievers, R. F., and Ryon, J. B., Congenital idiopathic methemoglobinemia; favorable response to ascorbic acid therapy. Arch. Int. Med., 1945, 76, 299.

11. Slosse, A., and Wybauw, R., Un cas de méthémoglobinémie idiopathique. Ann. et bull. Soc. roy. d. sc. méd. et nat. Brux., 1912, 70, 206.

12. Litarczek, G., Aubert, H., Cosmulesco, I., Comanesco, V., and Litarczek, S., Sur un cas de cyanose autotoxique par méthémoglobinémie intraglobulaire. Sang, 1930, 4, 188.

13. Leiner, G., and Minibeck, H., Ein Fall von intraglobulärer Methaemoglobinaemie. Wien. klin. Wchnschr., 1935, 48, 1547.

14. Gibson, Q. H., and Harrison, D. C., Familial idiopathic methaemoglobinaemia, five cases in one family. Lancet, 1947, 2, 941.

15. Bensley, E. H., Rhea, L. J., and Mills, E. S., Familial idiopathic methaemoglobinaemia. Quart. J. Med., N. S., 1938, 7, 325.

16. Evelyn, K. A., and Malloy, H. T., Micro determination of oxyhemoglobin, methemoglobin and sulfhemoglobin in a single sample of blood. J. Biol. Chem., 1938, 126, 655.

17. Peters, J. P., and Van Slyke, D. D., Quantitative Clinical Chemistry. Vol. II, Methods. Williams and Wilkins Co., Baltimore, 1932, p. 352.

18. Darling, R. C., and Roughton, F. J. W., The effect of methemoglobin on the equilibrium between oxygen and hemoglobin. Am. J. Physiol., 1942, 137, 56.

19. Darling, R. C., Personal communication.

20. Geiman, Q. M., Anfinsen, C. B., McKee, R. W. Ormsbee, R. A., and Ball, E. G., Studies on malarial parasites. VII. Methods and techniques for cultivation. J. Exper. Med., 1946, 84, 583.

21. Greenberg, L. A., Lester, D., and Haggard, H. W., The reaction of hemoglobin with nitrite. J. Biol. Chem., 1943, 151, 665.

22. Warburg, O., Kubowitz, F., and Christian, W., Uber die katalytische Wirkung von Methylenblau in lebenden Zellen. Biochem. Ztschr., 1930, 227, 245.

23. Wendel, W. B., Oxidations by erythrocytes and the catalytic influence of methylene blue. I. The oxidation of lactate to pyruvate. J. Biol. Chem., 1933, 102, 373.

24. Kiese, M., Erhaltung des Blutfarbstoffes in Funktionsfähigem Zustand. Klin. Wchnschr., 1946, 25, 81.

25. McKee, R. W., Omsbee, R. A., Anfinsen, C. B., Geiman, Q. M., and Ball, E. G., Studies on malarial parasites. VI. The chemistry and metabolism of normal and parasitized (P. Knowlesi) monkey blood. J. Exper. Med., 1946, 84, 569.

26. Ball, E. G., McKee, R. W., Anfinsen, C. B., Cruz, W. O., and Geiman, Q. M., Studies on malarial parasites. IX. Chemical and metabolic changes during growth and multiplication in vivo and in vitro. J. Biol. Chem., 1948, 175, 547.

27. Rapoport, S., and Guest, G. M., The distribution of acid-soluble phosphorus in the blood cells of various vertebrates. J. Biol. Chem., 1941, 138, 269. 
28. Rapoport, S., and Guest, G. M., The decomposition of diphosphoglycerate in acidified blood. Its relationship to reactions in the glycolytic cycle. J. Biol. Chem., 1939, 129, 781.

29. Peters, J. P., and Van Slyke, D. D., Quantitative Clinical Chemistry, Vol. I, Interpretations. Williams and Wilkins Co., Baltimore, 1932, pp. 1097, 1098.

30. Barrenscheen, H. K., and Vasarhelyi, B., Untersuchungen über die Glykolyse des Blutes. II. Pyrophosphatfraktion und Glykolyse. Biochem. Ztschr., 1931, 230, 330.

31. Harrop, G. A., Jr., and Barron, G. E. S., Studies on blood cell metabolism. I. The effect of methylene blue and other dyes upon the oxygen consumption of mammalian and avian erythrocytes. J. Exper. Med., 1928, 48, 207.

32. Williams, J. R., and Challis, F. E., Methylene blue as an antidote for anilin dye poisoning. J. Lab. \& Clin. Med., 1933, 19, 166.

33. Wendel, W. B., The control of methemoglobinemia with methylene blue. J. Clin. Invest., 1939, 18, 179.

34. Wendel, W. B., Methemoglobinemia. Modern Medical Therapy in General Practice, Vol. III. Edited by Barr, D. P., Williams and Wilkins Co., Baltimore, 1940, p. 3018.

35. Morgulis, S., Studies on the inactivation of catalase. III. Destruction of catalase by hydrogen peroxide. J. Biol. Chem., 1931, 92, 377.

36. Jusatz, H. J., Eine neue einfache Methode der quantitativen Bestimmung der Blutkatalase. Klin. Wchnschr., 1932, 11, 1188.
37. Butler, A. M., and Cushman, M., Distribution of ascorbic acid in the blood and its nutritional significance. J. Clin. Invest., 1940, 19, 459.

38. Fujita, A., and Numata, I., Uber die jodometrische Bestimmung des Glutathions in Geweben. Biochem. Ztschr., 1938, 299, 249.

39. Harrison, H. E., Personal communication.

40. Farr, L., Hiller, A., and Van Slyke, D. D., Personal communication.

41. Gibson, Q. H., The reduction of methaemoglobin by ascorbic acid. Biochem. J., 1943, 37, 615.

42. Barcroft, H., Gibson, Q. H., Harrison, D. C., and McMurray, J., Familial idiopathic methaemoglobinaemia and its treatment with ascorbic acid. Clin. Sc., 1945, 5, 145.

43. Van Slyke, D. D., Hiller, A., Weisiger, J. R., and Cruz, W. O., The determination of carbon monoxide in blood and of total and active hemoglobin by carbon monoxide capacity. Inactive hemoglobin and methemoglobin contents of normal human blood. J. Biol. Chem., 1946, 166, 121.

44. Gibson, Q. H., The reduction of methaemoglobin in red blood cells and studies on the cause of idiopathic methaemoglobinaemia. Biochem. J., 1948, 42, 13.

45. Gutmann, H., Jandorf, B., and Bodansky, O., The role of pyridine nucleotides in the reduction of methemoglobin. J. Biol. Chem., 1947, 169, 145.

46. Straub, F. B., Isolation and properties of a flavoprotein from heart muscle tissue. Biochem. J., 1939, 33, 787.

47. Kiese, M., Die Reduktion des Hämiglobins. Biochem. Ztschr., 1944, 316, 264. 